\title{
ADIKSI INTERNET PADA MASA DEWASA AWAL
}

\author{
Mutia Mawardah \\ Universitas Bina Darma \\ Jalan A. Yani No. 3 Palembang \\ Surel : mutia_mawardah@binadarma.ac.id
}

\begin{abstract}
This study aims to determine internet addiction in early adulthood. What aspects and factors influence addiction in early adulthood. Addiction shows psychological and physical characteristics. Physical dependence occurs when the body of an individual experiences dependence on certain substances and experiences "sakau" symptoms when removing their consumption. This study uses qualitative research design and uses phenomenological research to be able to find out addiction in early adulthood using a questionnaire from IADQ (Internet Addiction Diagnostic Questionnaire), which is a measure developed for diagnoses that conceptualizes the eight criteria for internet addiction disorders. In this study, researchers used five sources of research subjects. Data collection in this study was carried out using interview, observation, and documentation techniques on five subjects that have addiction to the subject's internet. The results of this study found that there is a neuropsychological chain model, namely there are six main concepts in relation to internet addiction, namely cognitive drive, euphoric experience, tolerance, abstinence reactions, passive coping and avalanche effects, and the results of research find there are factors that support internet addiction in middle adulthood, namely factors of interaction between internet users, factors available for internet facilities, factors of lack of supervision, factors of lack of motivation reduce internet usage in users and factors of users less able to control behavior in using the internet
\end{abstract}

\section{Keywords: internet addiction, early adult, cyberpsychology}

\begin{abstract}
Abstrak : Penelitian ini bertujuan untuk mengetahui adiksi internet pada dewasa awal. Aspek dan factor apa saja yang mempengaruhi adiksi pada masa dewasa awal. Kecanduan memperlihatkan ciri-ciri psikologis maupun fisik. Ketergantungan fisik terjadi ketika tubuh seorang individu mengalami ketergantungan pada zat tertentu dan mengalami gejala-gejala sakau ketika mengehntikan konsumsinya. Penelitian ini menggunakan design penelitian kualitatif serta menggunakan penelitian fenomenologis untuk dapat mengetahui adiksi pada masa dewasa awal dengan menggunakan kuesioner dari IADQ (Internet Addiction Diagnostic Questionnaire), yaitu ukuran yang dikembangkan untuk diagnosis yang mengkonseptualisasikan kedelapan kriteria untuk gangguan adiksi internet. Dalam penelitian ini, peneliti menggunakan lima orang sumber subjek penelitian. Pengumpulan data dalam penelitian ini dilakukan dengan menggunakan teknik wawancara, observasi, dan dokumentasi pada lima subjek yang memiliki adiksi pada internet subjek. Hasil penelitian ini menemukan bahwa adanya model rantai secara neuropsikologis, yaitu terdapat enam konsep utama dalam kaitannya dengan adiksi internet, yaitu dorongan kognitif, pengalaman euforik, toleransi, reaksi abstinensi, coping pasif dan efek longsoran, dan hasil penelitian menemukan ada faktor yang mendukung adiksi internet pada masa dewasa madya, yaitu faktor adanya interaksi antar pengguna internet, faktor tersedia fasilitas internet, faktor kurang pengawasan, faktor kurangnya motivasi mengurangi penggunaan internet dalam diri pengguna dan faktor pengguna kurang mampu mengontrol perilaku dalam menggunakan internet.
\end{abstract}

Kata Kunci: adiksi internet, dewasa awal, psikologi siber 


\section{PENDAHULUAN}

Perkembangan yang pesat beberapa tahun ini di bidang teknologi komunikasi dan informasi membawa perubahan dalam segala aspek kehidupan manusia. Diantara kemajuan teknologi komunikasi dan informasi yang menjadi sorotan adalah penyediaan layanan Internet (Interconnection Networking). Ellswort \& Ellswort (Felita dkk., 2016) mengungkapkan bahwa internet adalah suatu jaringan besar yang terdiri dari jaringan-jaringan komputer yang dapat menghubungkan komputer dan orang-orang diseluruh dunia melalui media telepon, satelit, dan sistem komunikasi lainnya. Internet pertama kali dikenalkan kepada masyarakat yaitu pada tahun 1972, dan hingga saat ini internet berkembang begitu pesat (Felita dkk, 2016). Saat ini internet menjadi sebuah gaya hidup baru bagi penggunanya bahkan dapat dikatakan jika internet telah menjadi bagian dari kehidupan sehari-hari.

Berdasarkan data dari Internet World Stats pada tahun 2019 Indonesia merupakan negara kelima yang menggunakan internet terbanyak dari seluruh negara didunia. Hal ini sejalan dengan survei terakhir yang dilakukan APJII (Asosiasi Pengelenggara Jasa Internet Indonesia) pada tahun 2017 yang menyatakan bahwa pengguna internet di Indonesia mengalami peningkatan setiap tahunnya dengan siginifikan.
Pada tahun 2007 pengguna internet di Indonesia sebanyak 20 juta, kemudian pada tahun 2012 naik menjadi sebanyak 63 juta, dan kembali mengalami kenaikan pada tahun 2017 sebanyak 143,26 juta.

Pengguna internet di Indonesia jika dilihat dari setiap wilayah provinsi memiliki jumlah pengguna yang berbeda-beda. Pengguna internet terbesar di wilayah Provinsi Sumatera yaitu berasal dari Provinsi Bengkulu sebesar 85\%, kemudian Provinsi Sumatera Barat yaitu sebesar 84,20\%, Provinsi Sumatera Utara sebesar 75,30\%. Sedangkan Provinsi Sumatera Selatan berada di urutan tujuh untuk pengguna internet di wilayah Sumater yaitu sebesar $64,40 \%$. Lalu yang berada diurutan terakhir atau Provinsi yang memiliki jumlah pengguna internet sedikit yaitu Provinsi Lampung sebesar $39,50 \%$.

Pengguna internet jika dilihat berdasarkan jenis kelamin maka sebanyak $48,57 \%$ pengguna internet adalah wanita dan $51,43 \%$ pengguna internet adalah laki-laki. Jika dilihat dari komposisi pengguna internet berdasarkan usia, sebanyak 49,52\% pengguna internet masih tergolong kedalam masa dewasa muda yang berusia sekitar 18 25 tahun (Santrock, 2011). Menurut Arnett (Santrock, 2011) rentang usia masa dewasa muda adalah 18-25 tahun sedangkan menurut Hurlock (2015) usia dewasa muda adalah 1840 tahun. Dewasa muda atau dewasa awal adalah masanya bekerja dan jatuh cinta, 
terkadang hanya menyisakan sedikit untuk hal-hal lainnya.

Berdasarkan hasil riset yang di keluarkan Google pada bulan Maret 2015, Indonesia mengalami pertumbuhan dua kali lipat dalam penggunaan smartphone (ponsel pintar) dengan data dari $14 \%$ menjadi $28 \%$ dalam satu tahun. Dari penelitian itu, terungkap $62 \%$ pengguna di Indonesia yang disurvei menggunakan smartphone untuk mengakses internet (Felita dkk, 2016). Berdasarkan data dari Internet World Stats pada tahun 2019 Indonesia menempati salah satu posisi teratas di dunia yakni nomor tiga untuk di Asia dan nomor lima untuk di dunia terkait dengan akses internet eksklusif dari smartphone. Berdasarkan data survei dari APJII (Asosiasi Pengelenggara Jasa Internet Indonesia) yaitu sebanyak $87,13 \%$ pengguna internet menggunakan internet untuk berinteraksi melalui media sosial (APJII, 2017).

Caplan (2002) melihat kecanduan teknologi sebagai sebuah subset kecanduan perilaku; kecanduan internet menunjukkan ciri-ciri komponen inti adiksi (yaitu salience, modifikasi mood [suasana perasaan], toleransi, withdrawal, konflik, dan relapse [kambuh]).

Greenfield (Young \& Cristiano 2017) menyatakan bahwa pengguna yang diklasifikasikan sebagai pengguna internet yang mengalami ketergantungan atau Adiksi Internet Pada Masa Dewasa Awall.. kecanduan pada umumnya berlebihan dalam penggunaan internet dan menghabiskan waktu antara 40 jam sampai 80 jam perminggu. Pengguna media sosial dapat dikatakan juga sebagai pengguna internet, mengingat syarat agar pengguna dapat mengakses media sosial yaitu harus terhubung dengan jaringan internet.

Istilah kecanduan internet (adiksi internet), pertama kali dimunculkan oleh Dr. Kimberly Young pada tahun 1996 (Young, 2017). Menurut Orzack (Young, 2017) pecandu internet menunjukkan kehidupan yang menjadi tidak terkendali serta hilangnya kendali impuls dalam dirinya dan penderita tidak dapat meninggalkan internet. Menurut salah satu penelitian, para pengguna internet yang tidak mengalami ketergantungan (kecanduan) sebagian besar mengakses surel dan situs-situs tertentu. Sedangkan yang mengalami ketergantungan (kecanduan) akan menghabiskan waktu untuk online dengan menggunakan aplikasi komunikasi interpersonal sinkron (Young, 2017).

Penggunaan istilah adiksi atau kecanduan internet pertama kali digunakan pada tahun 1996 dan hasil temuan mengenai kecanduan internet (adiksi internet) dipresentasikan di American Psychological Association. Penelitian tersebut mengulas lebih dari 600 kasus pengguna berat internet yang .. (Mutia Mawardah) 110 
memperlihatkan tanda-tanda klinis kecanduan sebagaimana diukur melalui versi kriteria DSM-IV yang sudah diadaptasi untuk judi patologis (Young, 2017).

Griffiths (2000) menyatakan bahwa kecanduan internet (adiksi internet) belum di akui dalam DSM V, meskipun telah ada pembicaraan mengenai hal tersebut dan fenomena kecanduan tersebut. American Psychiatric Association (Young, 2017) menyatakan bahwa internet dapat membawa mereka yaitu pengguna ke keadaan yang tampaknya memenuhi definisi gangguan mental DSM yang dideskripsikan sebagai sindroma perilaku atau psikologis yang siginifikan secara klinis terakit dengan yang di alami saat ini atau resiko yang meningkat secara signifikan untuk mengalami kematian, kesakitan, disabilitas, atau kehilangan kebebasan.

Kebanyakan orang yang kecanduan internet ini dikarenakan mereka menemukan kepuasan di internet, yang tidak mereka dapatkan di dunia nyata. Internet telah membuat remaja kecanduan, karena di internet menawarkan berbagai fasilitas informasi, mainan, dan hiburan yang membuat remaja tidak ingin meninggalkan internet. Kebanyakan mereka terperangkap pada aktivitas negatif seperti games, judi dan sex online walaupun tidak semua (Ningtyas, 2012).

Kecanduan internet memiliki ciri-ciri khusus untuk mengetahui apakah pengguna termasuk kedalam kecanduan internet atau tidak. Adapun ciri-ciri tersebut menurut Young (Mutohharoh dkk, 2014) adalah merasa senang ketika online (mengakses internet), merasa tidak senang, gelisah, tertekan atau lekas marah ketika offline (tidak mengakses internet), tidak mampu mengatur pengunaan internet, serta menggunakan internet untuk melarikan diri dari masalah.

Berdasarkan fenomena mengenai adiksi (kecanduan) internet yang terdapat pada masa dewasa awal maka peneliti tertarik untuk mengkaji dan meneliti Intensitas Penggunaan Media Sosial dengan Adiksi Internet Pada Masa Dewasa Awal.

\section{METODOLOGI PENELITIAN}

Metode dalam penelitian ini menggunakan pendekatan kualitatif, kualitatf merupakan prosedur penelitian yang menghasilkan data deskriptif, ucapan, atau tulisan dan perilaku yang diamati dari orangorang (subjek) itu sedniri. Pendekatan ini langsung menunjukkan latar belakang dan individu-individu dalam latar itu secara keseluruhan (Ahmadi, 2014)

Herdiansyah (2015) menyatakan studi fenomenologis menggambarkan arti sebuah pengalaman hidup untuk beberapa orang tentang sebuah konsep atau fenomena. Orang-orang yang terlibat dalam menangani sebuah fenomena melakukan eksplorasi 
terhadap struktur kesadaran pengalaman hidup manusia. Penelitian ini dilakukan di Palembang, Sumatera Selatan.

Teknik pengumpuan data yang dilakukan dalam penelitian ini adalah wawancara semi terstruktur (semistructure interview). Tujuan dari wawancara jenis ini adalah untuk menemukan permasalahan secara lebih terbuka, dimana pihak yang diajak wawancara diminta pendapat, ideidenya. Dalam melakukan wawancara, peneliti mendengarkan secara teliti dan mencatat apa yang dikemukan oleh interviewee (Sugiyono, 2017).

$\begin{array}{cccr}\text { Mendeteksi } & \text { secara } & \text { klinis } & \text { pemakaian } \\ \text { kompulsif } & \text { internet } & \text { adalah } & \text { dengan }\end{array}$
membandingkanna dengan kriteria kecanduan lain yang sudah mapan. Kecanduan internet dengan sindroma-sindroma adiktif yang serupa dengan gangguan-gangguan penegndalian impuls pada Skala Aksis I dalam DSM (American Psychiatric Association, 1994) dan menggunakan berbagai kriteria berbasis-DSM-IV untuk menefiniskan kecanduan internet.

Adapun guide interview yang digunakan mengacu kepada Internet Addiction Diagnostic Questionnaire (IADQ), yaitu ukuran penyaringan kriteria untuk gangguan adiksi internet oleh Young (1998). Kuesioner IADQ mengkonseptualisasikan kedelapan kriteria untuk gangguan tersebut, yakni :

1. Apakah anda merasa terpreokupasi dengan internet (memikirkan tentang kegiatan online sebelumnya atau mengantisipasi sesi online yang akan datang)?
2. Apakah anda merasakan kebutuhan untuk menggunakan internet dalam waktu yang lebih lama untuk mencapai kepuasan?

3. Apakah anda melakukan upaya berulangulang yang semuanya gagal untuk mengontrol, mengurangi, atau menghentikan pemakaian internet?

4. Apakah anda merasa gelisah, suasana perasaan anda berubah-ubah, depresi, atau mudah tersinggung ketika mencoba mengurangi atau menghentikan penggunaan internet?

5. Apakah anda online lebih lama daripada yang awalnya anda inginkan?

6. Apakah anda menghadapi risiko kehilangan hubungan yang signifikan, pekerjaan, atau peluang pendidikan atau karier akibat internet?

7. Pernahkan anda membohongi anggota keluarga, terapis, atau orang lain untuk menutupi keterlibatan anda dengan internet?

8. Apakah anda menggunakan internet sebagai cara untuk melarikan diri dari masalah atau meredakan suasana perasaan disforik (misalnya, merasa tidak berdaya, merasa bersalah, cemas, depresi)?

Pada penelitian ini peneliti menggunakan teknik observasi passive participation yang dikemukakan oleh Spradley (Sugiyono, 2017). Pada teknik Passive Participation (partisipasi pasif) peneliti datang ke tempat kegiatan subjek yang diamati tetapi tidak ikut terlibat dalam kegiatan tersebut. Teknik observasi ini dilakukan untuk mengetahui penggunaan internet dalam keseharian subjek 


\section{HASIL DAN PEMBAHASAN}

Sebelum melakukan proses observasi dan wawancara, peneliti meminta subjek mengisi terlebih dahulu skala adiksi internet IAT (Internet Addiction Test) untuk mengetahui skor yang diperoleh. Apabila memenuhi syarat yaitu mendapatkan skor adiksi internet yang tinggi, subjek berusia 21-25 tahun yang masuk dalam masa dewasa awal, maka peneliti akan menghubungi subjek untuk bertanya kesediaan subjek diwawancara. Setelah mendapatkan persetujuan, peneliti akan mulai melakukan proses observasi dan wawancara dengan subjek.

Subjek pertama (S1) adalah seorang perempuan berusia 22 tahun, mahasiswi di salah satu perguruan tinggi swasta di Kota Palembang, menjadi adiksi dikarenakan menjadi lebih bebas dalam bersosialisasi. Subjek kedua (S2) adalah seorang perempuan berusia 24 tahun, salah satu karyawan swasta di Kota Palembang, menjadi adiksi internet dikarenakan tuntutan pekerjaan yang menggunakan internet. Subjek ketiga (S3) adalah seorang laki-laki berusia 22 tahun, salah satu mahasiswa non aktif di salah satu perguruan tinggi negeri di Kota Palembang, menjadi adiksi internet dikarenakan melakukan aktivitas bermain game online. Subjek keempat (S4) adalah seorang laki-laki berusia 23 tahun, salah satu karyawan swasta di sebuah perusahaan, menjadi adiksi dikarenakan salah satu cara problem solving dalam melepaskan stress. Dan subjek kelima (S5) adalah seorang perempuan berusia 22 tahun, mahasiswi salah satu perguruan tinggi negeri di Kota Palembang.

Berdasarkan dari pernyataan penelitian maka diperoleh hasil dari wawancara kelima subjek, bahwa mereka menjadi adiksi (kecanduan) internet adalah penggunaan media sosial yang berlebihan dalam hal intensitas dan memiliki pengaruh yang besar pada adiksi internet.

Subjek dianggap mengalami ketergantungan ketika menjawab dengan membenarkan lima pertanyaan atau lebih selama jangka waktu enam bulan. Bagianbagian yang dikaitkan dengan penggunaan internet yang biasanya berlebihan, mengabaikan tugas rutin atau tanggungjawab hidup, isolasi sosial, dan sembunyi-sembunyi dalam melakukan kegiatan online, atau tibatiba ada permintaan privasi selama online.

$$
\text { Beard dan Wolf }
$$
merekomendasikan kelima kriteria pertama disyaratkan untuk diagnosis kecanduan internet, karena kriteria ini dapat dipenuhi tanpa menghendaya fungsi sehari-hari seseorang. Direkomendasikan juga bahwa paling tidak salah satu diantara kriteria terakhir dari IADQ (misalnya kriteria 6,7, atau 8) disyaratkan dalam mendiagnosis kecanduan internet. Alasan dipisahkannya 
ketiga kriteria tersebut berdampak pada kemampuan pengguna patologis internet untuk mengatasi masalah dan menjalankan fungsinya (misalnya depresi, kecemasan, lari dari masalah) dan juga berdampak pada interaksinya dengan orang lain (misalnya hubungan yang signifikan, pekerjaan, tidak jujur dengan orang lain).

Subjek mengatakan ketika menggunakan internet, perhatiannya hanya akan tertuju pada apa yang dibuka menggunakan internet, misalnya media sosial sehingga akan tidak fokus ketika terdapat orang lain yang sedang berbicara dengan dirinya. Durasi dan frekuensi yang dihabiskan pun mampu lebih dari delapan jam dalam sehari dan mampu membuka media sosial lebih dari empat kali dalam sehari.

Bahkan mereka menggunakan internet tersebut ketika sedang melakuakan aktivitas di jam-jam kerja atau kuliah. Ketika sedang melakukan aktivitas yang lainnya, mereka juga tetap menggunakan internet seperti sedang makan, sedang ke toilet, dan belajar. Dari hasil penelitian yang telah dilakukan, mereka akan lebih memilih untuk membeli kuota dibandingkan dengan buku.

Caplan (Young, 2017) melihat kecanduan (adiksi) internet sebagai kecanduan perilaku yang menunjukkan ciri- ciri utama dari adiksi internet yaitu salience, modifikasi suasana hati, toleransi, withdrawal (mengidamkan atau menginginkan objek), konflik, dan relapse (kambuh). Selain itu, ia juga mengatakan bahwa pengguna internet yang dalam hal ini pengguna media sosial, menggunakan media sosial sebagai salah satu cara untuk lari atau keluar dari perasaan yang meresahkan, mencapai kepuasan, mengalami withdrawal ketika mengurangi penggunaan internet, dan mengalami peningkatan konflik akibat penggunaan internet yang berlebihan.

Ciri-ciri adiksi internet yang dikemukakan oleh Caplan (Young \& Cristiano, 2017) juga dapat dilihat pada subjek. Ketika sedang menghadapi masalah, mereka akan memilih untuk aktif di internet untuk menenangkan diri mereka dari masalah yang dihadapi. Bagi mereka, konten-konten yang tersedia di internet dapat membuat dirinya menjadi lebih tenang dan terhibur. Bahkan terdapat informasi atau berbagai macam motivasi yang berkaitan dengan permasalahan mereka yang bisa didapatkan hanya dengan aktif di media sosial.

Tingkat adiksi internet subjek akan dipengaruhi oleh beberapa faktor yang salah satunya adalah intensitas. Ajzen (2005) menyatakan bahwa intensitas adalah suatu 
usaha yang dilakukan individu dalam melakukan suatu tindakan tertentu. Individu yang melakukan suatu usaha tertentu memiliki pola dan perilaku yang sama dimana hal tersebut dilakukan untuk mendapatkan pemuas kebutuhannya. Dalam hal ini subjek akan melakukan suatu tindakan berupa aktif di media sosial dengan intensitas yang berlebihan dan dilakukan berulangulang sehingga telah menjadi kebiasaan. Hal tersebut dilakukan untuk memenuhi kebutuhannya dan merasa senang serta puas (Meinamara, 2019)

Dilihat dari model neuropsikologis China Youth Association for Netwaork Development (2005) mengemukakan standar untuk memutuskan kecanduan internet memiliki satu prasyarat dan tiga kondisi. Persyaratannya adalah bahwa kecanduan internet itu harus sangat membahayakan fungsi social dan komunikasi interpersonal seseorang, kemudian tiga kondisi berikut : (1) subjek merasa bahwa lebih mudah untuk mencapai aktualisasi diri online disbanding di dalam kehidupan nyata; (2) subjek akan mengalami disforia atau depresi bilamana akses ke internet terputus atau berhenti berfungsi; (3) subjek berusaha menyembunyikan waktu penggunaan sebenarnya dari anggota keluarganya. Berikut model rantai neuropsikologis untuk menjelaskan perilaku adiktif-internet.

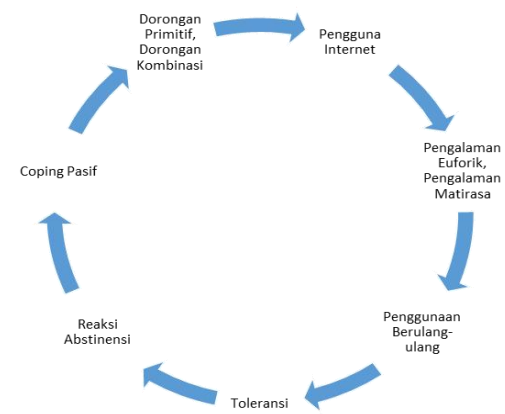

Gambar 1 model rantai neuropsikologis

kecanduan internet

Penjelasan kaitan neuropsikologis kecanduan internet, terbagi menjadi enam konsep utama, yaitu : (1) dorongan primitive, insting individu untuk mengejar kenikmatan dan menghindari rasa sakit, yang merepresentasikan beragam motif dan impuls atau dorongan untuk menggunakan internet; (2) pengalaman euforik, aktivitas internet menstimulasi system saraf pusat individu, yang akan merasa senang dan puas. Perasaan itu akan mendorong individu untuk terus menggunakan internet dan memperpanjang euforianya; (3) toleransi, akibat penggunaan internet yang berulang-ulang, ambang batas sensorik individu meningkat, untuk mencapai pengalaman kesenangan yang sama, pengguna harus menambah waktu dan hasratnya; (4) reaksi abstinensi, sindroma fisik dan psikologis terjadi ketika individu berhenti atau setelah penggunaan internetnya berkurang, terutama meliputi disforia, insomnia, ketidakstabilan emosi,, iritabilitas, dan sebaginya; (5) coping pasif, perilakuperilaku pasif yang mengakomodasi lingkungan terbentuk ketika individu dihadapkan pada frustasi atau menerima 
efek-efek merugikan dari luar, yang meliputi perilaku-perilaku pasif seperti imputasi kejadian yang tidak menyenangkan, falsifikasi kognisi, dan supresi, penghindaran, dan agresi yang terbentuk; (6) efek longsoran, avalanche effect, termasuk pengalaman pasif yang terdiri atas toleransi dan reaksi abstinensi, dan dorongan kombinasi yang terdiri atas gaya coping pasif yang didasarkan pada dorongan primitive individu.

Jika dilihat dari durasi penggunaan internet pada subjek, sebagain besar mampu menghabiskan waktu lebih dari lima sehari, bahkan terdapat pula yang mampu menghabiskan waktu hingga 12-16 jam sehari hanya untuk mengakses media sosial.

Kelima subjek mengalami adiksi internet. Hal tersebut dapat ditunjukkan dengan jawaban dari beberapa pertanyaan yang mengenai faktor dan dampak negatif adiksi internet.

Pada umumnya adiksi internet yang ditemukan pada laki-laki adalah adiksi game online sedangkan pada perempuan adalah adiksi media sosial. Paska \& Yan (Mulyati \& Frieda, 2018) menjelaskan bahwa gender dapat mempengaruhi jenis aplikasi yang digunakan dan penyebab individu mengalami adiksi internet. Pada perempuan lebih sering mengalami kecanduan (adiksi) terhadap chatting (media sosial) dan berbelanja secara online. Sedangkan pada laki-laki lebih sering mengalami kecanduan terhadap game online.

Pernyataan Paska \& Yan (Mulyati \& Frieda, 2018) juga dikemukakan oleh dr. Kristiana Siste, $\operatorname{SpKJ}(\mathrm{K})$ dalam seminarnya yang berjudul Dampak Penggunaan Gadget Pada Anak dan ia kutip dari penelitian Penelitian tahun 2015 mengatakan bahwa pada laki-laki akan banyak ditemukan mengalami adiksi game online karena lakilaki memiliki interaksi sosial yang lebih buruk dibandingkan dengan perempuan. Sedangkan pada perempuan akan banyak ditemukan mengalami adiksi media sosial karena memiliki interaksi sosial yang lebih baik dan mampu berkomunikasi dengan baik.

Shapiro, dkk (2003) mengemukakan pendekatan untuk mendiagnosis kecanduan internet berdasarkan gangguan pengendalian impuls menurut DSM-IV-TR (American Psychiatric Association, 2000) yang lebih memperluas lagi kriteria diagnostic untuk penggunaan problematic internet. Termasuk diantaranya preokupasi maladatif dengan penggunaan internet, seperti diindikasikan oleh preokupasi yang tidak dapat ditolak dengan internet atau penggunaan eksesif internet untuk jangka waktu yang lebih lama daripada yang direncanakan.

Berdasarkan hasil penelitian tersebut maka dapat disimpulkan bahwa intensitas 
penggunaan media sosial memiliki pengaruh yang kecil terhadap adiksi internet pada subjek dan terdapat faktor lain yang menyebabkan subjek mengalami adiksi internet.

\section{SIMPULAN}

Berdasarkan hasil yang diperoleh dari data dan pembahasan dengan menggunakan metode penelitian kualitatif, maka dapat ditarik kesimpulan bahwa terdapat aspek-aspek dan factor-faktor yang dialami subjek yang termasuk dalam kategori dewasa awal kea rah adiksi internet.

Pada penelitian metode kualitatif dapat disimpulkan bahwa subjek mengalami adiksi internet tidak hanya disebabkan oleh media sosial dan game online. Namun, juga disebabkan oleh faktor berupa aplikasi lain yang berbasis internet seperti youtube, google, dan viu. Berdasarkan hasil wawancara dengan subjek maka dapat disimpulkan bahwa kelima subjek menyatakan faktor yang menyebabkan adiksi internet dan mengalami dampak negatif dari penggunaan internet yang berlebihan. 


\section{DAFTAR RUJUKAN}

Ahmadi, R. (2014). Metode Penelitian Kualitatif. Yogyakarta : Ar-Ruzz Media

Ajzen, I. (2005). Attitudes, Personality and Behavior, (2 ${ }^{\text {nd }}$ edition), Berkshire, UK: Open University Press-McGraw Hill Education.

American Psychiatric Association. (2000). Diagnostic and statistical manual of mental disorder (DSM) (edisi ke-4). Washington, DC: Author.

APJII. (2017). Penetrasi dan Perilaku Pengguna Internet Indonesia. Iinfografis Hasil Survey, 1-39.

Beard, K. W., \& Wolf, E. M. (2001). Modification in the proposed diagnostic criteria for internet addiction. CyberPsychology \& Behavior, 4, 377383.

China Youth Association for Network Development (CYAND). (2005). Report of China Teenagers' internet addiction information 2005 (Beijing, China).

Felita, P., Siahaja, C., Wijaya, V., Melisa, G., Chandra, M., Dahesihsari, R., Jaya, U. A. (2016). Pemakaian Media Sosial dan Self Concept Pada Remaja. Jurnal Ilmiah Psikologi MANASA, 1, 30-41.

Herdiansyah, H. (2015). Metode Peneitian Kualitatif Untuk Ilmu Psikologi. Jakarta Selatan: Salemba Humanika.
Hurlock, E. B. (2015). Psikologi Perkembangan, Suatu Pendekatan Sepanjang Rentang Kehidupan (terjemahan). Jakarta: Erlangga.

Meinamara, A. (2019). Intensitas Penggunaan Media Sosial Dengan Adiksi Internet Pada Mahasiswa Univeritas Bina Darma. (Skripsi, Tidak Diterbitkan). Fakultas Psikologi Universitas Bina Darma.

Mulyati, T., \& Frieda, N. R. H. (2018). Kecanduan Smartphone Ditinjau Dari Kontrol Diri dan Jenis Kelamin Pada Siswa SMA Mardisiswa Semarang. Jurnal Empati, 7, 154.

Mutohharoh, A., Kusumaputri, E. S., Psikologi, P. S., Islam, U., \& Sunan, N. (2014). Teknik pengelolaan diri perilakuan dalam menurunkan kecanduan internet pada mahasiswa yogyakarta behavioral self-management technique in decreasing internet addiction on yogyakarta university students. Humanitas: Indonesian Psychological Journal, 1, 102-124.

Ningtyas, S. D. (2013). Hubungan Antara Self Control dengan Internet Addiction pada Mahasiswa. Educational Psychology Journal, 1, 25-30.

Santrock, John. W. (2011). Life Span Development. Jakarta: Erlangga.

Shapiro, N. A., Lessig, M. C., Goldsmith, T. D., Szabo, S. T., Lazoritz, M., Gold, M. S.,\& Stein, D. J. (2003). Problematic 
internet use: Proposed classifictaion and diagnostic criteria. Depression and Anxiety, 17, 207-216.

Sugiyono. (2017). Metode Penelitian Kombinasi (Mixed Methods). Bandung: Alfabeta.

Young, K. S. (1998). internet addiction: The emergence of a new clinical disorder. CyberPsychology \& Behavior, 1, 237244.

Young, K. S., \& Cristiano, N. (2017). Kecanduan Internet. Yogyakarta: Pustaka Pelajar. 